\title{
1 Phytochemicals in Legumes: A Qualitative Reviewed Analysis
}

2 Alba Tor-Roca, ${ }^{\dagger}$ Mar Garcia-Aloy, ${ }^{\dagger, \star \S}$ Fulvio Mattivi ${ }^{\S, \#, ~ R a f a e l ~ L l o r a c h, ~}{ }^{\dagger}, \star$ Cristina

3 Andres-Lacueva, ${ }^{\dagger, *}$ Mireia Urpi-Sarda $*, \dagger, *$

4

$5 \dagger$ Biomarkers and Nutrimetabolomics Laboratory, Department of Nutrition, Food Science

6 and Gastronomy, Food Technology Reference Net (XaRTA), Institute for Research on

7 Nutrition and Food Safety (INSA-UB), Food and Nutrition Torribera Campus, Faculty of

8 Pharmacy and Food Sciences, University of Barcelona, Barcelona, Spain.

$9 *$ Centro de Investigacion Biomedica en Red (CIBER) on Frailty and Healthy Ageing

10 (CIBERFES), Instituto de Salud Carlos III, Barcelona, Spain.

$11{ }^{\S}$ Department of Food Quality and Nutrition, Research and Innovation Centre, Fondazione

12 Edmund Mach (FEM), 38010 San Michele all'Adige, Italy.

$13{ }^{\#}$ Department of Cellular, Computational and Integrative Biology (CIBIO), University of

14 Trento, 38123 Povo, Italy.

15

16 Corresponding Author

17 *Mireia Urpi-Sarda. E-mail: murpi@ ub.edu

18

19

20

21 


\section{ABSTRACT}

24 Legumes are an excellent source of nutrients and phytochemicals. They have been 25 recognized for their contributions to health, sustainability and the economy. Although

26 legumes comprise several species and varieties, little is known about the differences in

27 their phytochemical composition and the magnitude of these. Therefore, the aim of this

28 review is to describe and compare the qualitative profile of phytochemicals contained in

29 legumes and identified through LC-MS and GC-MS methods. Among the 478

30 phytochemicals reported in 52 varieties of legumes, phenolic compounds were by far the

31 most frequently described $(n=405,85 \%)$. Metabolomics data analysis tools were used

32 to visualize the qualitative differences, showing beans to be the most widely analyzed

33 legumes and those with the highest number of discriminant phytochemicals $(n=180$,

$3438 \%$ ). A Venn diagram showed that lentils, beans, soybeans and chickpeas shared only

$357 \%$ of their compounds. This work highlighted the huge chemical diversity among

36 legumes, identified the need for further research in this field, and the use of metabolomics

37 as a promising tool to achieve it.

38 KEYWORDS: phytochemicals, legumes, qualitative analysis, nutrimetabolomics, 39 polyphenols

40 


\section{INTRODUCTION}

42 Legumes have been shown to promote health and reduce the risk of cardiovascular disease

43 (CVD) as well as that of some cancers, such as colon cancer, among other pathological

44 conditions. ${ }^{1,2}$ They also have particular relevance for sustainability and local economies,

45 as they reduce greenhouse gas emissions, help decrease animal-based protein

46 consumption and are rooted in communal gastronomies. ${ }^{3}$ In the last few decades, legumes

47 have gained popularity worldwide as being a good source of phytochemical compounds.

48 Phytochemicals are non-nutrient plant-based minor components that differ substantially

49 in their biochemistry, source distribution and physiological effects. Their biological

50 activities, such as antioxidant, ${ }^{4}$ anti-inflammatory ${ }^{5}$ and antimicrobial ${ }^{6}$, have also been

51 described, and it has been suggested that they offer significant meaningful benefits to

52 human health. ${ }^{4}$ The vast majority of studies conducted to describe the phytochemical

53 composition of legumes have focused on only one type of legume ${ }^{7-9}$ or on a small number

54 of phytochemicals. The comparison of legumes from a phytochemical profile viewpoint

55 is essential for distinguishing properties and potential applications of legumes as well as

56 for enhancing the state of the art and promoting their production, consumption and use.

57 Therefore, the aim of this review is to describe and compare the qualitative profile of

58 bioactive compounds contained in legumes for human consumption that have been

59 identified through LC-MS and GC-MS methods.

60 In this review, we described the qualitative profile of phytochemicals contained in

61 legumes for human consumption which had been identified through LC-MS and GC-MS

62 methods. We followed this description by conducting a comparative analysis between the

63 different groups of legumes using statistical dichotomous techniques. Finally, a

64 description of bioactive compounds that could discriminate between legumes was

65 discussed. 
67 Definition and types of pulses and legumes. Legumes are the edible seeds of the

68 Fabaceae or Leguminosae family, the third-largest group of plants (more than 20,000

69 species and 700 genera). They produce between 1 and 12 grains of various sizes, shapes

70 and colors within a pod. Having been spread across the world for about 90 million years,

71 even in regions with extreme weather, their seeds have been used for at least 10,000 years

72 for both human and animal consumption. ${ }^{10}$

73 The Food and Agricultural Organization (FAO) considered pulses a subgroup of legumes

74 and are defined as "Leguminosae crops harvested exclusively for their grain, including

75 chickpeas, dry beans, peas and lentils". This definition excludes legumes harvested for

76 oil extraction, such as soybeans and peanuts, and those used as vegetables, like green

77 beans and green peas. ${ }^{10}$ Specifically, the FAO recognizes the following 11 primary

78 pulses: dry beans (kidney, pinto, navy, azuki, mung, black gram, scarlet runner, rice bean,

79 moth and tepary beans), dry broad beans (horse, broad and field bean), dry peas (garden

80 and field pea), chickpeas, dry cowpeas (cowpea and black-eyed pea/bean), pigeon peas

81 (pigeon pea and cajan pea), lentils, Bambara beans (Bambara groundnut and earth pea),

82 vetch (spring/common vetch), lupins and other "minor" pulses (hyacinth or lablab, jack

83 or sword, winged, velvet, guar and yam beans). ${ }^{11}$ In order to homogenize the concepts,

84 we will use in this review the more generic term "legumes" to refer to both pulses and

85 legumes for human consumption: soybeans, peanuts, chickpeas, lentils, beans and peas

86 (Table S1).

87 Legumes are considered an essential superfood, not only thanks to their desirable

88 nutritional profile and health properties but also to their great influence and power in two

89 other key human aspects: the environment and society.

90 Nutritional composition and health effects. Recent studies have brought to light the 
91 relationship between a regular consumption of legumes and the prevention of some

92 chronic diseases (Table 1). A daily intake of legumes is associated with a decreased risk

93 of CVD, especially coronary heart disease (CHD). ${ }^{13}$ In fact, legumes consumption leads

94 to the reduction of various CVD risk factors, such as LDL cholesterol, ${ }^{14,15}$ total

95 cholesterol, ${ }^{15}$ blood pressure, ${ }^{13}$ body weight, ${ }^{16,17}$ glycemic index (GI), ${ }^{18,19}$ insulin

96 resistance ${ }^{20}$ and C-reactive protein, ${ }^{21}$ among other metabolic syndrome risk factors. ${ }^{22}$ This

97 is due to several compositional traits of legumes, specifically their amount of potassium, ${ }^{23}$

98 magnesium $^{24}$ and soluble fiber, ${ }^{25}$ along with their cholesterol-free condition ${ }^{1}$ (Table 1 ).

99 Findings also suggest an inverse association between the intake of legumes and the risk

100 of prostate cancer. ${ }^{26}$ One possible explanation for this could be their phytoestrogen

101 content. ${ }^{27}$ Additionally, maternal consumption of legumes during pregnancy may have a

102 protective effect on acute lymphoblastic leukemia in children. ${ }^{28}$ Furthermore, it has been

103 suggested that consuming legumes could reduce the risk of breast cancer, ${ }^{29}$ due mainly to

104 their flavonol, flavone and isoflavone content, ${ }^{30-33}$ although evidence is still limited. ${ }^{34}$ As

105 regards endometrial cancer, findings of a meta-analysis suggest a weak inverse

106 association between consumption of isoflavones from soy products and legumes and

107 endometrial cancer risk. ${ }^{35}$ Although previous meta-analysis and systematic reviews ${ }^{36}$

108 supported the notion that a high intake of legumes was also associated with a low

109 incidence of colorectal cancer due to their high fiber content, ${ }^{25}$ an update of the evidence

110 of the WCRF-AICR (World Cancer Research Fund-American Institute for Cancer

111 Research) Continuous Update Project states that legume intake is not associated with

112 colorectal cancer risk ${ }^{37}$ (Table 1).

113 Finally, having a low GI and fat content, as well as a high fiber content, increases satiety ${ }^{38}$

114 and helps stabilize blood sugar and insulin levels. This makes legumes ideal for weight

115 management. ${ }^{16,17}$ 
116 On the other hand, it seems that legumes consumption has no effect either on stroke risk

117 or diabetes risk. ${ }^{13}$ Despite this, legumes can possibly have effects on their biomarkers. In

118 the case of stroke risk, this can be explained by the amount of potassium they contain ${ }^{23}$

119 and their capacity to reduce glycemic load, ${ }^{39}$ whereas in the case of diabetes risk, this

120 seems to be due to the replacement of animal protein for vegetable protein effect, ${ }^{19}$ as

121 well as for the improvement of longer-term glycemic control markers and the reduction

122 of metabolic syndrome risk factors. ${ }^{18,22}$

123 This beneficial role of legumes could be explained by their desirable nutritional and non-

124 nutritional profile. Legumes have a high amount of complex carbohydrates and fiber,

125 thereby offering an average low-energy density of $1.3 \mathrm{kcal} / \mathrm{g} .{ }^{1}$ They are also known for

126 being poor in sodium and rich in other minerals, like potassium, zinc, calcium and iron. ${ }^{1,40}$

127 Legumes are an excellent source of protein (20-30\% of their energy value), relatively

128 low in tryptophan and sulphur-containing amino acids, such as methionine and cysteine,

129 but rich in lysine. ${ }^{1,40}$ Moreover, they do not contain gluten. Their predominant fatty acid

130 is linoleic acid, ${ }^{40}$ and vitamins A, E and B are notably abundant. ${ }^{1}$ Legumes also contain a

131 high variety of phytochemicals and other minor components that have significant

132 meaningful benefits for human health: $\alpha$-galactosides, phytosterols, tocopherols,

133 saponins, alkaloids and phytic acid, as well as carotenoids and (poly)phenolic

134 compounds. ${ }^{1,41-47}$ Recent literature has shown that canning and household cooking

135 significantly differ in their effects on nutritional composition and bioactive content of

136 legumes, and even have contrary effects on different types of legumes. ${ }^{48}$ Agronomic,

137 storage, processing, food formulation, as well as bioaccessibility and bioavailability of

138 the phytochemicals are also factors involved in the ultimate health outcomes of

139 consumption of leguminous foods.

140 Despite the many health benefits of legumes, their cultivation and intake has been 
141 cautiously handled due to the presence of some bioactive compounds, such as phytic acid,

142 covicine, glucosinolates, protease and amylase inhibitors, as they can act as anti-nutrients.

143 Anti-nutritional factors may cause toxicity or interfere with the digestion and absorption

144 of certain dietary components, causing adverse physiological effects (for example,

145 flatulence, favism, lathyrism, small intestine damage and growth depression). ${ }^{41}$ This is

146 especially important since several legumes cause concern, particularly in areas

147 characterized by poverty and malnutrition where a single type of legume can be ingested

148 in high amounts. However, most anti-nutrients can still be reduced or removed by thermal

149 processing (boiling, steaming, roasting, autoclaving, dry heating), storage, irradiation,

150 soaking, de-hulling, milling, fermentation and germination. ${ }^{41,49}$

151

152 QUALITATIVE ANALYSIS OF PHYTOCHEMICALS IN LEGUMES

153 The qualitative profile of a large variety of legumes was obtained by applying the 154 systematic search referred to in the Supporting Information. A list of different varieties 155 of legumes and their phytochemicals was obtained after revising the literature.

156 Types of legumes. All the legumes reported on in this review are shown in Table S1. The

157 biggest group of legumes were beans, where 16 varieties belonged to Phaseolus vulgaris:

158 black, brown, cream, white, red, small red, cranberry, yellow, black Jamapa, red and

159 white kidney, pinto, brown string, yellow wax, pink and common beans. Two more kinds

160 of beans of the same genus were runner ( $P$. coccineus) and butter bean (P. lunatus) (Table

161 S1). Moreover, from the Vigna genus, nine different beans could be considered: black-

162 eyed bean and red cowpea ( $V$. unguiculata), mungo bean ( $V$. mungo), rice bean ( $V$.

163 umbellata), moth bean ( $V$. aconitifolia), black and green mung bean ( $V$. radiata), and

164 green and red adzuki bean (V. angularis). Finally, broad bean (Vicia faba), horse gram 
165 (Macrotyloma uniflorum), hyacinth bean (Lablab purpureus), black and red sword bean

166 (Canavalia gladiata), jack bean (Canavalia ensiformis), white lupin bean (Lupinus

167 albus), blue lupin bean (Lupinus angustifolius), yellow lupin bean (Lupinus luetus) and

168 morama bean (Tylosema esculentum) are also part of this group (Table S1). From Lens

169 culinaris, commonly known as lentils, seven varieties were considered. They were beluga

170 or black, brown, green, yellow, grey, red and tan lentils. Also, yellow and black

171 chickpeas (Cicer arietinum), green, black and yellow soybeans (Glycine max), and

172 peanuts (Arachis hypogaea) have been reported. Peas were grouped in three different

173 species: green and yellow pea (Pisum sativum), snowpea (Pisum sativum var.

174 saccharatum) and pigeon pea (Cajanus cajan).

175 Phytochemical foodprint of legumes. The search gave a total of 478 phytochemicals

176 described in legumes. The biggest group was condensed tannins $(\mathrm{n}=90)$, which

177 represented 19\%, followed by flavonols $(n=79)$, isoflavones $(n=64)$ and phenolic acids

$178(\mathrm{n}=63)$, which represented $17 \%, 13 \%$ and $13 \%$, respectively. The following have also

179 been reported: $5 \alpha$-galactosides, 33 saponins, 6 phytosterols, 2 lignans, 1 coumestan, 3

180 tocopherols, 12 alkaloids, 6 stilbenes, 4 dihydrochalcones, 2 pterocarpans, 31 flavones,

18120 flavanones, 4 flavanonols, 17 flavanols, 1 hydrolysable tannin, 21 anthocyanidins, 11

182 carotenoids and 3 other compounds (Table 2 and Table S3). Therefore, phenolic

183 compounds were the major family of phytochemicals described in legumes, with 405 of

184 them (85\%). The second-biggest family was saponins, with 33 constituents (7\%) (Table

1852 and Table S3).

186 In regard to phytochemical families and legume groups, the literature showed that phytic

187 acid, saponins, phytosterols, tocopherols, lignans, phenolic acids, isoflavones, flavonols

188 and flavanols have been identified in all kinds of legumes, whereas carotenoids were

189 found in lentils, chickpeas, beans and soybeans but not in peas or peanuts (Table 2 and 
190 Table S3). Ciceritol, an $\alpha$-galactoside, has been determined in all legumes except 191 peanuts, ${ }^{41,50}$ whilst anthocyanidins were found in lentils, beans and soybeans. ${ }^{51-57}$ 192 Moreover, alkaloids were only identified in beans and peas, ${ }^{7,58-61}$ but flavanonols were 193 found in beans and peanuts. ${ }^{7,8,54,62,63}$ Since dihydrochalcones, pterocarpans, hydrolysable 194 tannins and brazilin had only previously been described in beans, ${ }^{7,54,64,65}$ to the best of our 195 knowledge no raffinose family of oligosaccharides (RFO) in peanuts and no coumestans 196 in peas have been determined before. Finally, soybeans had no stilbenes, flavones or 197 squalene, and chickpeas lacked flavanones and condensed tannins.

198 In addition, Table 2 also shows the particular composition of each group of legumes, with 199 beans being the group with the most compounds identified $(\mathrm{n}=276,58 \%)$, followed by 200 peanuts, soybeans and lentils $(n=120,112$ and 101, respectively), while only 60 and 66 201 chemicals were reported in chickpeas and peas, respectively.

202 Qualitative cluster analysis of legumes. In this review, we decided to use visualization 203 tools to evidence the state of the art of the phytochemicals in legumes. A heatmap analysis 204 was constructed by using MetaboAnalyst $3.0^{66}$ employing the qualitative data (Figure 1, 205 Figure S1, Figure S2, Table S3). This heatmap shows the distribution of bioactive 206 substances, according to each legume, that were or were not determined in them. In 207 parallel with the heatmap, Table S4 shows the 372 discriminant compounds, marked in 208 red in Figure 1, that were determined in the specific legumes. The group with the highest 209 number of discriminant compounds $(n=180)$ was beans, representing around $38 \%$ of all 210 compounds. Flavonols were the main phytochemicals that allowed beans to be 211 discriminated from other legumes (e.g. quercetin 3-O-xylosyloglucoside ${ }^{67}$ and 212 faralatroside $\left.{ }^{54}\right)$. The next groups of legumes in terms of proportion were peanuts and 213 soybeans, where $18 \%$ and $14 \%(n=85$ and $n=69)$, respectively, of their compounds 214 allowed them to be discriminated from the other legumes. Peanuts stand out for 
215 condensed tannins (e.g. prorobinetidin and prodelphinidin ${ }^{8}$ ) and soybeans for isoflavones

216 (e.g. daidzein O-di-hexoside and genistein O-hexoside ${ }^{68}$ ). There were 27 specific

217 compounds from lentils (Table S4), with carotenoids (e.g. 9-cis-lutein and 9-cis-

218 zeaxantin ${ }^{69}$ ) being the most prevalent, amounting to $6 \%$ of the total. Otherwise, chickpeas

219 and peas had only a very few unique compounds, with each amounting to only $1 \%$ of all

220 specific compounds ( $\mathrm{n}=6$ and $\mathrm{n}=5$, respectively).

221 Therefore, given that some phytochemicals have only been determined or identified in

222 one type of legume, such as canthoxanthine in chickpeas, glycitin and derivates in

223 soybeans, several alkaloids such as lupanine and angustifoline in beans and morin in peas

224 (Table S4), future analytical needs should be oriented toward validating whether these

225 compounds are exclusive to these legumes or whether legumes have not been fully

226 analyzed. For instance, although the literature is extensive in this field, recently other

227 works have revealed the presence of some phytochemicals in different legumes by

228 applying untargeted metabolomic approaches to foodprint them,${ }^{70}$ indicating that this is a

229 niche area to study.

230 Additionally, in our qualitative review, we identified a total of 14 phytochemicals that

231 were distributed among all groups of legumes. These compounds were $\alpha$-tocopherol, ${ }^{69,71-}$

$232 \quad \beta 5+\gamma$-tocopherol, ${ }^{52,69,71-76} \quad \beta$-sitosterol, ${ }^{71-74,77,78} \quad$ campesterol, ${ }^{71-74,77,78}$

233 stigmasterol, ${ }^{71,73,74,77,78}$ biochanin $\quad \mathrm{A}^{8,63,79-81}$ formononetin, ${ }^{7,63,79,80}$ daidzein, ${ }^{63,79-81}$

234 genistein, ${ }^{7,68,72,79-81}$ genistin, ${ }^{80-82}$ epi-catechin, ${ }^{8,9,52,63,72,83-88}$ phytic acid, ${ }^{41,61,64,89-94}$

235 secoisolariciresinol ${ }^{79,95}$ and soyasaponin $\mathrm{Bb},{ }^{96-98}$ which are basically phytosterols and

236 isoflavones. Consequently, none of them are shown in the heatmap.

237 Principal component analysis of phytochemical composition of legumes. Principal

238 component analysis (PCA) was applied to the data to highlight qualitative differences and

239 similarities between legumes (Figure 2). Principal component 1 (PC1) was responsible 
240 for $44.2 \%$ of the variance, whereas PC2 and PC3 explained $23.7 \%$ and $17.8 \%$,

241 respectively. The most qualitative difference was obtained between beans and the other

242 legumes (PC1). In addition, peanuts and soybeans also had quite a different profile from

243 the other legumes. They are positioned in the bottom-left and top-left corner, respectively,

244 of the PCA score plot. In fact, $65 \%$ of the compounds determined in beans were

245 exclusively identified in them, whilst in the case of soybeans and peanuts, the proportion

246 was $62 \%$ and $71 \%$, respectively. On the other hand, chickpeas, lentils and peas have quite

247 a central position in the PCA score plot (Figure 2). Only $27 \%$ of the compounds reported

248 in lentils were specifically identified in them, while in the case of chickpeas and peas, the

249 proportion was $10 \%$ and $8 \%$, respectively. The PCA score plot revealed a close cluster

250 between lentils, chickpeas and peas, where 35 compounds were shared only among them

251 (Figure 2B), representing 32\% of the chemicals found in peas, 35\% of the compounds

252 reported in chickpeas and $21 \%$ of the phytochemicals identified in lentils (Table S5).

253 Most of them were phenolic acids, isoflavones and flavonols. Additional score plot 3D

254 showed that lentils were separated from chickpeas and peas in the PC3 (Figure 2C).

255 Venn diagram analysis. A Venn diagram of the four groups has been created with the 256 most well-known, widely considered ${ }^{11}$ and popular legumes (lentils, beans, chickpeas and 257 soybeans) for better interpretation and visualization of the data. The obtained diagram ${ }^{99}$ 258 allows us to visualize the proportion of the number of phytochemicals by group (Figure 259 3). Lentils, soybeans, beans and chickpeas had 26 shared compounds (7\%), mainly 260 isoflavones. Lentils and soybeans were the only ones in which soyasaponin $\mathrm{Bd}$ 261 (isoflavone) was identified, while sinapic, chlorogenic and cinnamic acids (phenolic 262 acids), luteolin 8-C-glucoside (flavone), myricetin 3-O-rhamnoside, quercetin 3-O263 galactoside (flavonols) and $\beta$-carotene were identified in beans and chickpeas. Both 264 chickpeas and lentils contained gentisic acid (phenolic acid). There was no specific 
265 compound shared between soybeans, beans and chickpeas or between soybeans, lentils

266 and chickpeas either.

\section{CONCLUSIONS AND FUTURE PERSPECTIVES}

269 In the present work, a phytochemical foodprint of 478 phytochemicals from 52 varieties

270 of legumes has been extracted from literature. This foodprint includes 405 phenolic

271 compounds (which constitute the main group of phytochemicals), 33 saponins, 12

272 alkaloids, 11 carotenoids, 6 phytosterols, $5 \alpha$-galactosides, 3 tocopherols, phytic acid,

273 brazilin and squalene. Metabolomic techniques have been used for the first time for

274 visualizing qualitative differences between legumes. Beans are the most widely analyzed

275 legumes globally and have the highest number of their own phytochemicals $(n=180$,

$27638 \%$ of the total), followed by peanuts $(n=85,18 \%$ of the total), soybeans $(n=69,14 \%$

277 of the total) and lentils $(n=27,6 \%$ of the total), with the proportion being $1 \%$ for

278 chickpeas and peas. The qualitative PCA suggested that beans had the most differentiated

279 profile, while lentils, chickpeas and peas revealed a central and close position with a high

280 number of shared compounds. In addition, the Venn diagram showed that lentils,

281 chickpeas, soybeans and beans shared only $7 \%$ of their determined compounds.

282 This work has allowed us to identify several niches to be developed in this field. In

283 particular, future research directions should be aimed at establishing an exhaustive

284 approach to uncovering the whole profile of some legumes, since our review indicates

285 that there are meaningful differences between legumes. This is the case for peas and 286 chickpeas, whose phytochemical profile is numerically far below the other legumes' 287 foodprint.

288 It is recommended that future research should work toward increasing our knowledge 
289 about the underrepresented groups of phytochemicals, such as tocopherols and other 290 nonpolyphenolic compounds, in order to obtain more complete phytochemical profiles of 291 legumes. Identification of these phytochemical profiles will enable their synergistic effect 292 on bioavailability to be studied, along with the mechanism of action and biological 293 function, and finally enhance our understanding of the health benefits and suitability for 294 human consumption of each type of legume. This new knowledge will also be useful for 295 quantifying these phytochemicals and for obtaining biomarkers of compliance, as well as 296 enabling better quality control of legume-based foods.

\section{ABBREVIATIONS USED}

301 CHD: coronary heart disease; CVD: cardiovascular diseases; FAO: Food and Agriculture 302 Organization; GI: glycemic index; PCA: principal component analysis; RoM: ratio of 303 means; RFO: raffinose family of oligosaccharides; WCRF-AICR: World Cancer 304 Research Fund-American Institute for Cancer Research 


\section{FUNDING SOURCES}

307 This research was supported by the EU Joint Programming Initiative 'A Healthy Diet for 308 a Healthy Life' on Biomarkers BioNH FOODBALL (PCIN-2014-133 Ministry of 309 Economy and Competitiveness (MINECO) Spain); ERA-Net cofund on Intestinal 310 Microbiomics (INTIMIC) Project "AC19/00096" by Instituto de Salud Carlos III and co311 funded by European Regional Development Fund "A way to make Europe"; CIBERFES 312 (co-funded by the FEDER Program from EU); Fundació La Marató de TV3 (project ref. 313 201943-30-31); Italian Ministry of Education, University and Research (MIUR, CUP 314 D43C17000100006), and the 2017SGR1546 grant from the Generalitat de Catalunya 315 Agency AGAUR. ATR is grateful for the FI-DGR 2019 (AGAUR) contract and CAL to 316 the ICREA Academia award 2018 from the Generalitat de Catalunya.

318 Note: The authors declare no competing financial interest. 


\section{SUPPORTING INFORMATION DESCRIPTION}

321 Research and visualization methodology, binomial and common name of each legume

322 reported in the review (Table S1), legend of phytochemicals (PC) numbers with their

323 corresponding names of phytochemicals (Table S2), families and phytochemicals

324 described in legumes (Table S3), potential discriminant phytochemicals of each group of 325 legumes according to the bibliographic search (Table S4), phytochemicals shared 326 between legumes (Table S5), qualitative heatmap of the phytochemicals distributed in 327 legumes (detailed version; Figure S1) (PDF) and original overview of the qualitative 328 heatmap file from MetaboAnalyst 3.0 (Figure S2).

329 


\section{REFERENCES}

(1) Mudryj, A. N.; Yu, N.; Aukema, H. M. Nutritional and Health Benefits of Pulses. Appl. Physiol. Nutr. Metab. 2014, 39 (11), 1197-1204. https://doi.org/10.3945/ajcn.113.071472.

(2) Rebello, C. J.; Greenway, F. L.; Finley, J. W. Whole Grains and Pulses: A Comparison of the Nutritional and Health Benefits. Journal of Agricultural and Food Chemistry. American Chemical Society July 2014, pp 7029-7049. https://doi.org/10.1021/jf500932z.

(3) Magrini, M. B.; Anton, M.; Chardigny, J. M.; Duc, G.; Duru, M.; Jeuffroy, M. H.; Meynard, J. M.; Micard, V.; Walrand, S. Pulses for Sustainability: Breaking Agriculture and Food Sectors Out of Lock-In. Front. Sustain. Food Syst. 2018, 2. https://doi.org/10.3389/fsufs.2018.00064.

(4) Zhang, Y. J.; Gan, R. Y.; Li, S.; Zhou, Y.; Li, A. N.; Xu, D. P.; Li, H. Bin; Kitts, D. D. Antioxidant Phytochemicals for the Prevention and Treatment of Chronic Diseases. $\quad$ Molecules 2015, $20 \quad$ (12), 21138-21156. https://doi.org/10.3390/molecules201219753.

(5) Zhu, F.; Du, B.; Xu, B. Anti-Inflammatory Effects of Phytochemicals from Fruits, Vegetables, and Food Legumes: A Review. Crit. Rev. Food Sci. Nutr. 2018, 58 (8), 1260-1270. https://doi.org/10.1080/10408398.2016.1251390.

(6) Borges, A.; Saavedra, M.; Simoes, M. Insights on Antimicrobial Resistance, Biofilms and the Use of Phytochemicals as New Antimicrobial Agents. Curr. Med. Chem. 2015, $22 \quad$ (21), 2590-2614. https://doi.org/10.2174/0929867322666150530210522.

(7) Abu-Reidah, I. M.; del Mar Contreras, M.; Arráez-Román, D.; FernándezGutiérrez, A.; Segura-Carretero, A. UHPLC-ESI-QTOF-MS-Based Metabolic 
Profiling of Vicia Faba L. (Fabaceae) Seeds as a Key Strategy for Characterization in Foodomics. Electrophoresis 2014, 35, 1571-1581. https://doi.org/10.1002/elps.201300646.

(8) Ma, Y.; Kosinska-Cagnazzo, A.; Kerr, W. L.; Amarowicz, R.; Swanson, R. B.; Pegg, R. B. Separation and Characterization of Soluble Esterified and GlycosideBound Phenolic Compounds in Dry-Blanched Peanut Skins by Liquid Chromatography-Electrospray Ionization Mass Spectrometry. J. Agric. Food Chem. 2014, 62, 11488-11504. https://doi.org/10.1021/jf503836n.

(9) Zhang, B.; Deng, Z.; Tang, Y.; Chen, P. X.; Liu, R.; Ramdath, D. D.; Liu, Q.; Hernandez, M.; Tsao, R. Effect of Domestic Cooking on Carotenoids, Tocopherols, Fatty Acids, Phenolics, and Antioxidant Activities of Lentils (Lens Culinaris). J. Agric. Food Chem. 2014, 62, 12585-12594. https://doi.org/10.1021/jf504181r.

(10) Calles, T. The International Year of Pulses: What Are They and Why Are They Important? Agric. Dev. - Trop. Agric. Assoc. 2016, 1-3.

(11) Food and Agriculture Organization of the United Nations. Definition and classification of commodities: Pulses and derived products http://www.fao.org/es/faodef/fdef04e.htm\#4.01 (accessed Apr 29, 2017).

(12) Food And Agriculture Organization of the United Nations, F. Pulses: Nutritions Seeds for Sustainable Future. 2016, 1-196.

(13) Viguiliouk, E.; Glenn, A. J.; Nishi, S. K.; Chiavaroli, L.; Seider, M.; Khan, T.; Bonaccio, M.; Iacoviello, L.; Mejia, S. B.; Jenkins, D. J. A.; et al. Associations between Dietary Pulses Alone or with Other Legumes and Cardiometabolic Disease Outcomes: An Umbrella Review and Updated Systematic Review and Meta-Analysis of Prospective Cohort Studies. Adv. Nutr. 2019, 10, S308-S319. 
https://doi.org/10.1093/advances/nmz113.

381

(14) Ha, V.; Sievenpiper, J. L.; de Souza, R. J.; Jayalath, V. H.; Mirrahimi, A.; Agarwal, A.; Chiavaroli, L.; Mejia, S. B.; Sacks, F. M.; Di Buono, M.; et al. Effect of Dietary Pulse Intake on Established Therapeutic Lipid Targets for Cardiovascuar Risk Reduction: A Systematic Review and Meta-Analysis of Randomized Controlled Trials. Can. Med. Assoc. J. 2014, $186 \quad$ (8), 252-262. https://doi.org/10.1503/cmaj.131727/-/DC1.

(15) Bazzano, L. A.; Thompson, A. M.; Tees, M. T.; Nguyen, C. H.; Winham, D. M. Non-Soy Legume Consumption Lowers Cholesterol Levels: A Meta-Analysis of Randomized Controlled Trials. Nutr. Metab. Cardiovasc. Dis. 2011, 21 (2), 94103. https://doi.org/10.1016/j.numecd.2009.08.012.

(16) Kim, S. J.; Souza, R. J. De; Choo, V. L.; Ha, V.; Cozma, A. I.; Chiavaroli, L.; Mirrahimi, A.; Mejia, S. B.; Buono, M. Di; Bernstein, A. M.; et al. Effects of Dietary Pulse Consumption on Body Weight: A Systematic Review and MetaAnalysis of Randomized Controlled Trials. Am. J. Clin. Nutr. 2016, 103, 12131223. https://doi.org/10.3945/ajcn.115.124677.1.

(17) Schlesinger, S.; Neuenschwander, M.; Schwedhelm, C.; Hoffmann, G.; Bechthold, A.; Boeing, H.; Schwingshackl, L. Food Groups and Risk of Overweight, Obesity, and Weight Gain: A Systematic Review and Dose-Response Meta-Analysis of Prospective Studies. Advances in Nutrition. Oxford University Press 2019, pp 205218. https://doi.org/10.1093/advances/nmy092.

(18) Sievenpiper, J. L.; Kendall, C. W. C.; Esfahani, A.; Wong, J. M. W.; Carleton, A. J.; Jiang, H. Y.; Bazinet, R. P.; Vidgen, E.; Jenkins, D. J. A. Effect of Non-OilSeed Pulses on Glycaemic Control: A Systematic Review and Meta-Analysis of Randomised Controlled Experimental Trials in People with and without Diabetes. 
Diabetologia 2009, 52 (8), 1479-1495. https://doi.org/10.1007/s00125-009-1395-

406

407

408

409

410

411

412

413

414

415

416

417

418

419

420

421

422

423

424

425

426

427

428

429

7.

(19) Viguiliouk, E.; Stewart, S. E.; Jayalath, V. H.; Ng, A. P.; Mirrahimi, A.; de Souza, R. J.; Hanley, A. J.; Bazinet, R. P.; Mejia, S. B.; Leiter, L. A.; et al. Effect of Replacing Animal Protein with Plant Protein on Glycemic Control in Diabetes: A Systematic Review and Meta-Analysis of Randomized Controlled Trials. Nutrients 2015, 7 (12), 9804-9824. https://doi.org/10.3390/nu7125509.

(20) Schwingshackl, L.; Hoffmann, G.; Iqbal, K.; Schwedhelm, C.; Boeing, H. Food Groups and Intermediate Disease Markers: A Systematic Review and Network Meta-Analysis of Randomized Trials. American Journal of Clinical Nutrition. Oxford University Press September 2018, pp 576-586. https://doi.org/10.1093/ajen/nqy151.

(21) Salehi-Abargouei, A.; Saraf-Bank, S.; Bellissimo, N.; Azadbakht, L. Effects of Non-Soy Legume Consumption on C-Reactive Protein: A Systematic Review and Meta-Analysis. Nutrition. Elsevier Inc. 2015, pp 631-639. https://doi.org/10.1016/j.nut.2014.10.018.

(22) Mollard, R. C.; Luhovyy, B. L.; Panahi, S.; Nunez, M.; Hanley, A.; Anderson, G. H. Regular Consumption of Pulses for 8 Weeks Reduces Metabolic Syndrome Risk Factors in Overweight and Obese Adults. Br. J. Nutr. 2012, 108 (Suppl 1), S111S122. https://doi.org/10.1017/S0007114512000712.

(23) D’Elia, L.; Barba, G.; Cappuccio, F. P.; Strazzullo, P. Potassium Intake, Stroke, and Cardiovascular Disease: A Meta-Analysis of Prospective Studies. J. Am. Coll. Cardiol. 2011, 57 (10), 1210-1219. https://doi.org/10.1016/j.jacc.2010.09.070.

(24) Fang, X.; Liang, C.; Li, M.; Montgomery, S.; Fall, K.; Aaseth, J.; Cao, Y. DoseResponse Relationship between Dietary Magnesium Intake and Cardiovascular 
Mortality: A Systematic Review and Dose-Based Meta-Regression Analysis of Prospective Studies. J. Trace Elem. Med. Biol. 2016, 38, 64-73. https://doi.org/10.1016/j.jtemb.2016.03.014.

(25) Kim, Y.; Je, Y. Dietary Fibre Intake and Mortality from Cardiovascular Disease and All Cancers: A Meta-Analysis of Prospective Cohort Studies. Arch. $\begin{array}{llll}\text { Cardiovasc. } & \text { Dis. } & \text { 2016, } & 109\end{array}$ https://doi.org/10.1016/j.acvd.2015.09.005.

(26) Li, J.; Mao, Q. Legume Intake and Risk of Prostate Cancer: A Meta-Analysis of Prospective Cohort Studies. Oncotarget 2017, 8 (27), 44776-44784. https://doi.org/10.18632/oncotarget.16794.

(27) Zhang, M.; Wang, K.; Chen, L.; Yin, B.; Song, Y. Is Phytoestrogen Intake Associated with Decreased Risk of Prostate Cancer? A Systematic Review of Epidemiological Studies Based on 17.546 Cases. Andrology 2016, 4 (4), 745-756. https://doi.org/10.1111/andr.12196.

(28) Dessypris, N.; Karalexi, M. A.; Ntouvelis, E.; Diamantaras, A.-A.; Papadakis, V.; Baka, M.; Hatzipantelis, E.; Kourti, M.; Moschovi, M.; Polychronopoulou, S.; et al. Association of Maternal and Index Child's Diet with Subsequent Leukemia Risk: A Systematic Review and Meta Analysis. Cancer Epidemiol. 2017, 47, 6475. https://doi.org/10.1016/j.canep.2017.01.003.

(29) Mourouti, N.; Panagiotakos, D. B. Soy Food Consumption and Breast Cancer. Maturitas 2013, 76 (2), 118-122. https://doi.org/10.1016/j.maturitas.2013.07.006.

(30) Hui, C.; Qi, X.; Qianyong, Z.; Xiaoli, P.; Jundong, Z.; Mantian, M. Flavonoids, Flavonoid Subclasses and Breast Cancer Risk: A Meta-Analysis of Epidemiologic Studies. PLoS One 2013, 8 (1). https://doi.org/10.1371/journal.pone.0054318.

(31) Grosso, G.; Godos, J.; Lamuela-raventos, R.; Ray, S.; Micek, A.; Pajak, A.; 
Sciacca, S.; Del, D.; Galvano, F. A Comprehensive Meta-Analysis on Dietary Flavonoid and Lignan Intake and Cancer Risk : Level of Evidence and Limitations. Mol. Nutr. Food Res. 2017, 61 (4). https://doi.org/10.1002/mnfr.201600930.

(32) Xie, Q.; Chen, M.-L.; Qui, Y.; Zhang, Q.-Y.; Xu, H.-X.; Zhou, Y.; Mi, M.-T.; Zhu, J.-D. Isoflavone Consumption and Risk of Breast Cancer: A Dose-Response MetaAnalysis of Observational Studies. Asia Pacific J. Clin. Nutr. 2013, 22 (1), 118127. https://doi.org/10.6133/apjen.2013.22.1.16.

(33) Chen, M.; Rao, Y.; Zheng, Y.; Wei, S.; Li, Y.; Guo, T.; Yin, P. Association between Soy Isoflavone Intake and Breast Cancer Risk for Pre- and PostMenopausal Women: A Meta-Analysis of Epidemiological Studies. PLoS One 2014, 9 (2). https://doi.org/10.1371/journal.pone.0089288.

(34) World Cancer Research Fund/American Institute for Cancer Research. Continous Update Project Expert Report 2018. Diet, nutrition, physical activity and breast cancer. Aviable at dietandcancerreport.org.

(35) Zhong, X.; Ge, J.; Chen, S.; Xiong, Y.; Ma, S.; Chen, Q. Association between Dietary Isoflavones in Soy and Legumes and Endometrial Cancer: A Systematic Review and Meta-Analysis. J. Acad. Nutr. Diet. 2016, 1-15. https://doi.org/10.1016/j.jand.2016.09.036.

(36) Zhu, B.; Sun, Y.; Qi, L.; Zhong, R.; Miao, X. Dietary Legume Consumption Reduces Risk of Colorectal Cancer: Evidence from a Meta-Analysis of Cohort Studies. Sci. Rep. 2015, 5, 8797. https://doi.org/10.1038/srep08797.

(37) Vieira, A. R.; Abar, L.; Chan, D.; Vingeliene, S.; Polemiti, E.; Stevens, C.; Greenwood, D.; Norat, T. Foods and Beverages and Colorectal Cancer Risk: A Systematic Review and Meta-Analysis of Cohort Studies, an Update of the Evidence of the WCRF-AICR Continuous Update Project. Ann. Oncol. 2017. 
(38) Li, S. S.; Kendall, C. W. C.; De Souza, R. J.; Jayalath, V. H.; Cozma, A. I.; Ha, V.; Mirrahimi, A.; Chiavaroli, L.; Augustin, L. S. A.; Blanco Mejia, S.; et al. Dietary Pulses, Satiety and Food Intake: A Systematic Review and Meta-Analysis of Acute Feeding Trials. Obesity 2014, $22 \quad$ (8), 1773-1780. https://doi.org/10.1002/oby.20782.

(39) Fan, J.; Song, Y.; Wang, Y.; Hui, R.; Zhang, W. Dietary Glycemic Index, Glycemic Load, and Risk of Coronary Heart Disease, Stroke, and Stroke Mortality: A Systematic Review with Meta-Analysis. PLoS One 2012, 7 (12). https://doi.org/10.1371/journal.pone.0052182.

(40) Messina, M. J. Legumes and Soybeans: Overview of Their Nutritional Profiles and Health Effects. Am. J. Clin. Nutr. 1999, 70 (Suppl 3), S439-S450.

(41) Muzquiz, M.; Varela, A.; Burbano, C.; Cuadrado, C.; Guillamón, E.; Pedrosa, M. M. Bioactive Compounds in Legumes: Pronutritive and Antinutritive Actions. Implications for Nutrition and Health. Phytochem. Rev. 2012, 11, 227-244. https://doi.org/10.1007/s11101-012-9233-9.

(42) Campos-Vega, R.; Loarca-Piña, G.; Oomah, B. D. Minor Components of Pulses and Their Potential Impact on Human Health. Food Res. Int. 2010, 43 (2), 461482. https://doi.org/10.1016/j.foodres.2009.09.004.

(43) Amarowicz, R.; Pegg, R. B. Legumes as a Source of Natural Antioxidants. Eur. J. Lipid $\quad$ Sci. $\quad$ Technol. $\quad$ 2008, $110 \quad$ (10), $\quad 865-878$. https://doi.org/10.1002/ejlt.200800114.

(44) Champ, M. M.-J. Non-Nutrient Bioactive Substances of Pulses. Br. J. Nutr. 2002, 88 (Suppl 3), S307-S319. https://doi.org/10.1079/BJN2002721.

(45) Linus Pauling Institute (Oregon State University). Carotenoids: $\alpha$-Carotene, $\beta$ Carotene, $\quad \beta$-Cryptoxanthin, Lycopene, Lutein, and Zeaxanthin 
http://lpi.oregonstate.edu/mic/dietary-factors/phytochemicals/carotenoids (accessed May 8, 2017).

(46) Key, P. E.; Finglas, P. M.; Coldham, N.; Botting, N.; Oldfield, M. F.; Wood, R. An International Quality Assurance Scheme for the Quantitation of Daidzein and Genistein in Food, Urine and Plasma. Food Chem. 2006, 96 (2), 261-272. https://doi.org/10.1016/j.foodchem.2005.02.038.

(47) Tsao, R. Chemistry and Biochemistry of Dietary Polyphenols. Nutrients 2010, 2 (12), 1231-1246. https://doi.org/10.3390/nu2121231.

(48) Margier, M.; Georgé, S.; Hafnaoui, N.; Remond, D.; Nowicki, M.; Du Chaffaut, L.; Amiot, M. J.; Reboul, E. Nutritional Composition and Bioactive Content of Legumes: Characterization of Pulses Frequently Consumed in France and Effect of the Cooking Method. Nutrients 2018, 10 https://doi.org/10.3390/nu10111668.

(49) Food and Agriculture Organization (FAO). Anti-nutritional Factors Table http://www.fao.org/fishery/affrisapp/faofeed/vw_antinutritional_list.php?pagesiz $\mathrm{e}=500$ (accessed Jun 11, 2020).

(50) Quemener, B.; Brillouet, J. M. Ciceritol, a Pinitol Digalactoside Form Seeds of Chickpea, Lentil and White Lupin. Phytochemistry 1983, 22 (8), 1745-1751. https://doi.org/10.1016/S0031-9422(00)80263-0.

(51) Lin, L.-Z.; Harnly, J. M.; Pastor-Corrales, M. S.; Luthria, D. L. The Polyphenolic Profiles of Common Bean (Phaseolus Vulgaris L.). Food Chem. 2008, 107 (1), 399-410. https://doi.org/10.1016/j.foodchem.2007.08.038.

(52) Chen, P. X.; Tang, Y.; Marcone, M. F.; Pauls, P. K.; Zhang, B.; Liu, R.; Tsao, R. Characterization of Free, Conjugated and Bound Phenolics and Lipophilic Antioxidants in Regular- and Non-Darkening Cranberry Beans (Phaseolus 
185 ,

298-308. https://doi.org/10.1016/j.foodchem.2015.03.100.

(53) López, A.; El-Naggar, T.; Dueñas, M.; Ortega, T.; Estrella, I.; Hernández, T.; Gómez-Serranillos, M. P.; Palomino, O. M.; Carretero, M. E. Effect of Cooking and Germination on Phenolic Composition and Biological Properties of Dark Beans (Phaseolus Vulgaris L.). Food Chem. 2013, 138, 547-555. https://doi.org/10.1016/j.foodchem.2012.10.107.

(54) Abu-Reidah, I. M.; Arráez-Román, D.; Warad, I.; Fernández-Gutiérrez, A.; Segura-Carretero, A. UHPLC/MS2-Based Approach for the Comprehensive Metabolite Profiling of Bean (Vicia Faba L.) by-Products: A Promising Source of Bioactive Constituents. Food Res. Int. 2017, 93, 87-96. https://doi.org/10.1016/j.foodres.2017.01.014.

(55) Chang, Q.; Wong, Y. S. Identification of Flavonoids in Hakmeitau Beans (Vigna Sinensis) by High-Performance Liquid Chromatography-Electrospray Mass Spectrometry (LC-ESI/MS). J. Agric. Food Chem. 2004, 52, 6694-6699. https://doi.org/10.1021/jf049114a.

(56) Gan, R. Y.; Deng, Z. Q.; Yan, A. X.; Shah, N. P.; Lui, W. Y.; Chan, C. L.; Corke, H. Pigmented Edible Bean Coats as Natural Sources of Polyphenols with Antioxidant and Antibacterial Effects. LWT - Food Sci. Technol. 2016, 73, 168177. https://doi.org/10.1016/j.lwt.2016.06.012.

(57) Aparicio-Fernandez, X.; Yousef, G. G.; Loarca-Pina, G.; De Mejia, E.; Lila, M. A. Characterization of Polyphenolics in the Seed Coat of Black Jamapa Bean (Phaseolus Vulgaris L.). J. Agric. Food Chem. 2005, 53, 4615-4622. https://doi.org/10.1021/jf047802o.

(58) Nanna, R. S.; Banala, M.; Pamulaparthi, A.; Kurra, A.; Kagithoju, S. Evaluation 
of Phytochemicals and Fluorescent Analysis of Seed and Leaf Extracts of Cajanus Cajan L. Int. J. Pharm. Sci. Rev. Res. 2013, 22 (1), 11-18.

(59) Gefrom, A.; Ott, E. M.; Hoedtke, S.; Zeyner, A. Effect of Ensiling Moist Field Bean (Vicia Faba), Pea (Pisum Sativum) and Lupine (Lupinus Spp.) Grains on the Contents of Alkaloids, Oligosaccharides and Tannins. J. Anim. Physiol. Anim. Nutr. (Berl). 2013, 97, 1152-1160. https://doi.org/10.1111/jpn.12024.

(60) Musco, N.; Cutrignelli, M. I.; Calabr O, S.; Tudisco, R.; Infascelli, F.; Grazioli, R.; Presti, V. Lo; Gresta, F.; Chiofalo, B.; Calabr, S. Comparison of Nutritional and Antinutritional Traits among Different Species (Lupinus Albus L., Lupinus Luteus L., Lupinus Angustifolius L.) and Varieties of Lupin Seeds. J. Anim. Physiol. Anim. Nutr. (Berl). 2017, 1-15. https://doi.org/10.1111/jpn.12643.

(61) Gulewicz, P.; Martinez-Villaluenga, C.; Kasprowicz-Potocka, M.; Frias, J. NonNutritive Compounds in Fabaceae Family Seeds and the Improvement of Their Nutritional Quality by Traditional Processing - a Review. Pol J. Food Nutr. Sci. 2014, 64 (2), 75-89.

(62) Abu-Reidah, I. M.; Arráez-Román, D.; Lozano-Sánchez, J.; Segura-Carretero, A.; Fernández-Gutiérrez, A. Phytochemical Characterisation of Green Beans (Phaseolus Vulgaris L.) by Using High-Performance Liquid Chromatography Coupled with Time-of-Flight Mass Spectrometry. Phytochem. Anal. 2013, 24, 105-116. https://doi.org/10.1002/pca.2385.

(63) Leonora, M.; Francisco, D. L.; Resurreccion, A. V. A. Functional Components in Peanuts. Crit. Rev. Food Sci. Nutr. 2008, 48, 715-746. https://doi.org/10.1080/10408390701640718.

(64) Katoch, R. Nutritional Potential of Rice Bean (Vigna Umbellata): An Underutilized Legume. J. Food Sci. 2013, $78 \quad$ (1), C8-C16. 
https://doi.org/10.1111/j.1750-3841.2012.02989.x.

581

582

583

584

585

586

587

588

589

590

591

592

593

594

595

596

597

598

599

600

601

602

603

604

(65) Lampart-Szczapa, E.; Siger, A.; Trojanowska, K.; Nogala-Kalucka, M.; Malecka, M.; Pacholek, B. Chemical Composition and Antibacterial Activities of Lupin Seeds Extracts. Nahrung - Food 2003, $47 \quad$ (5), 286-290. https://doi.org/10.1002/food.200390068.

(66) Xia, J.; Wishart, D. S. Using MetaboAnalyst 3.0 for Comprehensive Metabolomics Data Analysis. In Current Protocols in Bioinformatics; John Wiley \& Sons, Inc.: Hoboken, NJ, USA, 2016; pp 14.10.1-14.10.91. https://doi.org/10.1002/cpbi.11.

(67) Lin, L.-Z.; Harnly, J. M.; Pastor-Corrales, M. S.; Luthria, D. L. The Polyphenolic Profiles of Common Bean (Phaseolus Vulgaris L.). Food Chem. 2008, 107 (1), 399-410. https://doi.org/10.1016/j.foodchem.2007.08.038.

(68) Cavaliere, C.; Cucci, F.; Foglia, P.; Guarino, C.; Samperi, R.; Laganà, A. Flavonoid Profile in Soybeans by High-Performance Liquid Chromatography/Tandem Mass Spectrometry. Rapid Commun. Mass Spectrom. 2007, 21, 2177-2187. https://doi.org/10.1002/rcm.3049.

(69) Zhang, B.; Deng, Z.; Tang, Y.; Chen, P.; Liu, R.; Ramdath, D. D.; Liu, Q.; Hernandez, M.; Tsao, R. Fatty Acid, Carotenoid and Tocopherol Compositions of 20 Canadian Lentil Cultivars and Synergistic Contribution to Antioxidant Activities. Food Chem. 2014, 161, 296-304. https://doi.org/10.1016/j.foodchem.2014.04.014.

(70) Llorach, R.; Favari, C.; Alonso, D.; Garcia-Aloy, M.; Andres-Lacueva, C.; UrpiSarda, M. Comparative Metabolite Fingerprinting of Legumes Using LC-MSBased Untargeted Metabolomics. Food Res. Int. 2019, 126. https://doi.org/10.1016/j.foodres.2019.108666.

(71) Campos-Vega, R.; Loarca-Piña, G.; Oomah, B. D. Minor Components of Pulses 
and Their Potential Impact on Human Health. Food Res. Int. 2010, 43 (2), 461482. https://doi.org/10.1016/j.foodres.2009.09.004.

(72) Kalogeropoulos, N.; Chiou, A.; Ioannou, M.; Karathanos, V. T.; Hassapidou, M.; Andrikopoulos, N. K. Nutritional Evaluation and Bioactive Microconstituents (Phytosterols, Tocopherols, Polyphenols, Triterpenic Acids) in Cooked Dry Legumes Usually Consumed in the Mediterranean Countries. Food Chem. 2010, 121, 682-690. https://doi.org/10.1016/j.foodchem.2010.01.005.

(73) Maguire, L. S.; O 'sullivan, S. M.; Galvin, K.; O 'connor, T. P.; O 'brien, N. M. Fatty Acid Profile, Tocopherol, Squalene and Phytosterol Content of Walnuts, Almonds, Peanuts, Hazelnuts and the Macadamia Nut. Int. J. Food Sci. Nutr. 2004, 55 (3), 171-178. https://doi.org/10.1080/09637480410001725175.

(74) Slavin, M.; Yu, L. A Single Extraction and HPLC Procedure for Simultaneous Analysis of Phytosterols, Tocopherols and Lutein in Soybeans. Food Chem. 2012, 135, 2789-2795. https://doi.org/10.1016/j.foodchem.2012.06.043.

(75) Boschin, G.; Arnoldi, A. Legumes Are Valuable Sources of Tocopherols. Food Chem. 2011, 127, 1199-1203. https://doi.org/10.1016/j.foodchem.2011.01.124.

(76) Kan, L.; Nie, S.; Hu, J.; Wang, S.; Cui, S. W.; Li, Y.; Xu, S.; Wu, Y.; Wang, J.; Bai, Z.; et al. Nutrients, Phytochemicals and Antioxidant Activities of 26 Kidney Bean Cultivars. 2016. https://doi.org/10.1016/j.fct.2016.09.007.

(77) Han, J. H.; Yang, Y. X.; Feng, M. Y. Contents of Phytosterols in Vegetables and Fruits Commonly Consumed in China. Biomed. Environ. Sci. 2008, 21, 449-453. https://doi.org/10.1016/S0895-3988(09)60001-5.

(78) Martins, C. M.; Fonseca, F. A.; Ballus, C. A.; Figueiredo-Neto, A. M.; Meinhart, A. D.; de Godoy, H. T.; Izar, M. C. Common Sources and Composition of Phytosterols and Their Estimated Intake by the Population in the City of Säo Paulo, 
Brazil. Nutrition 2013, 29, 865-871. https://doi.org/10.1016/j.nut.2012.12.017.

(79) Mazur, W. M.; Duke, J. A.; Wähälä, K.; Rasku, S.; Adlercreutz, H. Isoflavonoids and Lignans in Legumes: Nutritional and Health Aspects in Humans. J. Nutr. Biochem 1998, 9, 193-200.

(80) Konar, N.; Poyrazoĝlu, E. S.; Demir, K.; Artik, N. Determination of Conjugated and Free Isoflavones in Some Legumes by LC-MS/MS. J. Food Compos. Anal. 2012, 25, 173-178. https://doi.org/10.1016/j.jfca.2011.11.004.

(81) Vila-Donat, P.; Caprioli, G.; Maggi, F.; Ricciutelli, M.; Torregiani, E.; Vittori, S.; Sagratini, G. Effective Clean-up and Ultra High-Performance Liquid Chromatography-Tandem Mass Spectrometry for Isoflavone Determination in Legumes. Food Chem. 2015. https://doi.org/10.1016/j.foodchem.2014.11.047.

(82) Singleton, J. A.; Stikeleather, L. F.; Sanford, J. H. LC-Electrospray Ionization and LC-FABMS Study of Flavonoid Glycosides Extracted from Peanut Meal. J. Am. Oil Chem. Soc. 2002, 79 (8), 741-748.

(83) Tala, V. R. S.; Da Silva, V. C.; Rodrigues, C. M.; Nkengfack, A. E.; Dos Santos, L. C.; Vilegas, W. Characterization of Proanthocyanidins from Parkia Biglobosa (Jacq.) G. Don. (Fabaceae) by Flow Injection Analysis - Electrospray Ionization Ion Trap Tandem Mass Spectrometry and Liquid Chromatography/Electrospray Ionization Mass Spectrometry. Molecules 2013, 18 (3), 2803-2820. https://doi.org/10.3390/molecules18032803.

(84) Giusti, F.; Caprioli, G.; Ricciutelli, M.; Vittori, S.; Sagratini, G. Determination of Fourteen Polyphenols in Pulses by High Performance Liquid ChromatographyDiode Array Detection (HPLC-DAD) and Correlation Study with Antioxidant Activity and Colour. Food Chem. 2017, 221, 689-697. https://doi.org/10.1016/j.foodchem.2016.11.118. 
655

656

657

658

659

660

661

662

663

664

665

666

667

668

669

670

671

672

673

674

675

676

677

678

679

(85) Mirali, M.; Vandenberg, A.; Purves, R. W. Polyphenols in Whole Seed and Seed Coats of Lentil Market Classes. IFLRC VI ICLGG VII Conf. 2014. https://doi.org/10.13140/2.1.1215.5201.

(86) Bittner, K.; Rzeppa, S.; Humpf, H. U. Distribution and Quantification of Flavan3-Ols and Procyanidins with Low Degree of Polymerization in Nuts, Cereals, and Legumes. J. Agric. Food Chem. 2013, 61, 9148-9154. https://doi.org/10.1021/jf4024728.

(87) Jin, A.; Ozga, J. A.; Lopes-Lutz, D.; Schieber, A.; Reinecke, D. M. Characterization of Proanthocyanidins in Pea (Pisum Sativum L.), Lentil (Lens Culinaris L.), and Faba Bean (Vicia Faba L.) Seeds. FRIN 2012, 46, 528-535. https://doi.org/10.1016/j.foodres.2011.11.018.

(88) Ojwang, L. O.; Yang, L.; Dykes, L.; Awika, J. Proanthocyanidin Profile of Cowpea (Vigna Unguiculata) Reveals Catechin-O-Glucoside as the Dominant Compound. Food Chem. 2013, 139, 35-43. https://doi.org/10.1016/j.foodchem.2013.01.117.

(89) Lazarte, C. E.; Carlsson, N. G.; Almgren, A.; Sandberg, A. S.; Granfeldt, Y. Phytate, Zinc, Iron and Calcium Content of Common Bolivian Food, and Implications for Mineral Bioavailability. J. Food Compos. Anal. 2015, 39, 111119. https://doi.org/10.1016/j.jfca.2014.11.015.

(90) Thavarajah, D.; Thavarajah, P. Evaluation of Chickpea (Cicer Arietinum L.) Micronutrient Composition: Biofortification Opportunities to Combat Global Micronutrient Malnutrition. Food Res. Int. 2012, 49, 99-104. https://doi.org/10.1016/j.foodres.2012.08.007.

(91) Duhan, A.; Chauhan, B. M.; Punia, D.; Kapoor, A. C. Phytic Acid Content of Chickpea (Cicer Arietinum) and Black Gram (Vigna Mungo): Varietal Differences and Effect of Domestic Processing and Cooking Methods. J. Sci. Food Agric. 
1989, 49, 449-455. https://doi.org/10.1002/jsfa.2740490407.

(92) Lolas, G. M.; Markakis, P. Phytic Acid and Other Phosphorus Compunds of Beans (Phaseolus Vulgaris L.). J. Agric. Food Chem. 1975, 23 (1), 13-15.

(93) Steiner, T.; Mosenthin, R.; Zimmermann, B.; Greiner, R.; Roth, S. Distribution of Phytase Activity, Total Phosphorus and Phytate Phosphorus in Legume Seeds, Cereals and Cereal by-Products as Influenced by Harvest Year and Cultivar. Anim. Feed Sci. Technol. 2007, $320-334$. https://doi.org/10.1016/j.anifeedsci.2006.04.007.

(94) Gao, Y.; Shang, C.; Saghai Maroof, M. A.; Biyashev, R. M.; Grabau, E. A.; Kwanyuen, P.; Burton, J. W.; Buss, G. R. A Modified Colorimetric Method for Phytic Acid Analysis in Soybean. Crop Sci. 2007, 47, 1797-1803. https://doi.org/10.2135/cropsci2007.03.0122.

(95) Konar, N. Non-Isoflavone Phytoestrogenic Compound Contents of Various Legumes. Eur. Food Res. Technol. 2013, $236 \quad$ (3), 523-530. https://doi.org/10.1007/s00217-013-1914-0.

(96) Price, K. R.; Eagles, J.; Fenwick, G. R. Saponin Composition of 13 Varieties of Legume Seed Using Fast Atom Bombardment Mass Spectrometry. J. Sci. Food Agric. 1988, 42, 183-193. https://doi.org/10.1002/jsfa.2740420211.

(97) Ha, T. J.; Lee, B. W.; Park, K. H.; Jeong, S. H.; Kim, H. T.; Ko, J. M.; Baek, I. Y.; Lee, J. H. Rapid Characterisation and Comparison of Saponin Profiles in the Seeds of Korean Leguminous Species Using Ultra Performance Liquid Chromatography with Photodiode Array Detector and Electrospray Ionisation/Mass Spectrometry (UPLC-PDA-ESI/MS) Analysis. Food Chem. 2014, 146, 270-277. https://doi.org/10.1016/j.foodchem.2013.09.051.

(98) Sagratini, G.; Caprioli, G.; Maggi, F.; Font, G.; Giardinà, D.; Mañes, J.; Meca, G.; 
Ricciutelli, M.; Sirocchi, V.; Torregiani, E.; et al. Determination of Soyasaponins i and Bg in Raw and Cooked Legumes by Solid Phase Extraction (SPE) Coupled to Liquid Chromatography (LC)-Mass Spectrometry (MS) and Assessment of diagrams. Their Bioaccessibility by an in Vitro Digestion Model. J. Agric. Food Chem. 2013, 61, 1702-1709. https://doi.org/10.1021/jf304136g.

(99) Oliveros, J. C. Venny. An interactive tool for comparing lists with Venn's

(100) Fan, P. H.; Zang, M. T.; Xing, J. Oligosaccharides Composition in Eight Food Legumes Species as Detected by High-Resolution Mass Spectrometry. J. Sci. Food Agric. 2015, 95 (11), 2228-2236. https://doi.org/10.1002/jsfa.6940.

(101) Brummer, Y.; Kaviani, M.; Tosh, S. M. Structural and Functional Characteristics of Dietary Fibre in Beans, Lentils, Peas and Chickpeas. Food Res. Int. 2015, 67, 117-125. https://doi.org/10.1016/j.foodres.2014.11.009.

(102) Oboh, H. A.; Muzquiz, M.; Burbano, C.; Cuadrado, C.; Pedrosa, M. M.; Ayet, G.; Osagie, A. U. Anti-Nutritional Constituents of Six Underutilized Legumes Grown in Nigeria. J. Chromatogr. A 1998, 823, 307-312. https://doi.org/10.1016/S00219673(98)00542-1.

(103) Wang, N.; Hatcher, D. W.; Tyler, R. T.; Toews, R.; Gawalko, E. J. Effect of Cooking on the Composition of Beans (Phaseolus Vulgaris L.) and Chickpeas (Cicer Arietinum L.). Food Res. Int. 2010, 43, 589-594. https://doi.org/10.1016/j.foodres.2009.07.012.

(104) Rakshit, M.; Sharma, A.; Saha, J.; Sarkar, P. K. Optimization of Soaking Condition of Blackgram to Minimize Flatogenic Sugar Content in Blackgram-Based Products. LWT - Food Sci. Technol. 2015, 63, 814-820. https://doi.org/10.1016/j.lwt.2015.04.026. 
730

731

732

733

734

735

736

737

738

739

740

741

742

743

744

745

746

747

748

749

750

751

752

753

754

(105) Kotiguda, G.; Peterbauer, T.; Mulimani, V. H. Isolation and Structural Analysis of Ajugose from Vigna Mungo L. Carbohydr. Res. 2006, 341, 2156-2160. https://doi.org/10.1016/j.carres.2006.04.043.

(106) Kang, J.; Badger, T. M.; Ronis, M. J. J.; Wu, X. Non-Isoflavone Phytochemicals in Soy and Their Health Effects. J. Agric. Food Chem. 2010, 58, 8119-8133. https://doi.org/10.1021/jf100901b.

(107) Dueñas, M.; Hernández, T.; Estrella, I. Phenolic Composition of the Cotyledon and the Seed Coat of Lentils (Lens Culinaris L.). Eur. Food Res. Technol. 2002, 215, 478-483. https://doi.org/10.1007/s00217-002-0603-1.

(108) Arranz, S.; Silván, J. M.; Saura-Calixto, F. Nonextractable Polyphenols, Usually Ignored, Are the Major Part of Dietary Polyphenols: A Study on the Spanish Diet. Mol. Nutr. Food Res. 2010, 54, 1646-1658. https://doi.org/10.1002/mnfr.200900580.

(109) Hart, J. J.; Tako, E.; Kochian, L. V.; Glahn, R. P. Identification of Black Bean (Phaseolus Vulgaris L.) Polyphenols That Inhibit and Promote Iron Uptake by $\begin{array}{lllll}\text { Caco-2 Cells. } & \text { J. } & \text { Agric. }\end{array}$ https://doi.org/10.1021/acs.jafc.5b00531.

(110) Jackson, J. C.; Duodu, K. G.; Holse, M.; de Faria, M. D. L.; Jordaan, D.; Chingwaru, W.; Hansen, A.; Cencic, A.; Kandawa-Schultz, M.; Mpotokwane, S. M.; et al. The Morama Bean (Tylosema Esculentum). A Potential Crop for Southern Africa; 2010. https://doi.org/10.1016/B978-0-12-374468-5.00005-2.

(111) Magalhães, S. C. Q.; Taveira, M.; Cabrita, A. R. J.; Fonseca, A. J. M.; Valentão, P.; Andrade, P. B. European Marketable Grain Legume Seeds: Further Insight into Phenolic Compounds Profiles. Food Chem. 2017, 215, 177-184. https://doi.org/10.1016/j.foodchem.2016.07.152. 
755

756

757

758

759

760

761

762

763

764

765

766

767

768

769

770

771

772

773

774

775

776

777

778

779

(112) Monagas, M.; Garrido, I.; Lebrón-Aguilar, R.; Carmen Gómez-Cordovés, M.; Rybarczyk, A.; Amarowicz, R.; Bartolomé, B. Comparative Flavan-3-Ol Profile and Antioxidant Capacity of Roasted Peanut, Hazelnut, and Almond Skins. $J$. Agric. Food Chem. 2009, 57, 10590-10599. https://doi.org/10.1021/jf901391a.

(113) Stanisavljevic, N. S.; Ilic, M. D.; Matic, I. Z.; Jovanovic, Z. S.; Cupic, T.; Dabic, D. C.; Natic, M.; Tesic, Z. Identification of Phenolic Compounds from Seed Coats of Differently Colored European Varieties of Pea (Pisum Sativum L.) and Characterization of Their Antioxidant Ad in Vitro Anticancer Activities. Nutr. Cancer 2016, 68 (6), 988-1000.

(114) Bhatty, R. S. Composition and Quality of Lentil (Lens Culinaris Medik): A Review. Teehnol. J 1988, 21 (2), 144-160. https://doi.org/10.1016/S03155463(88)70770-1.

(115) Megías, C.; Cortés-Giraldo, I.; Alaiz, M.; Vioque, J.; Girón-Calle, J. Isoflavones in Chickpea (Cicer Arietinum) Protein Concentrates. J. Funct. Foods 2016, 21, 186-192. https://doi.org/10.1016/j.jff.2015.12.012.

(116) Sumner, L. W.; Paiva, N. L.; Dixon, R. A.; Geno, P. W. High-Performance Liquid Chromatography Continuous-Flow Liquid Secondary Ion Mass Spectrometry of Flavonoid Glycosides in Leguminous Plant Extracts. J. Mass Spectrom. 1996, 31

(5), 472-485. https://doi.org/10.1002/(sici)1096-9888(199605)31:5<472::aidjms318>3.0.co;2-e.

(117) Hanganu, D.; Vlase, L.; Olah, N. LC/MS Analysis of Isoflavones from Fabaceae Species Extracts. Farmacia 2010, 58 (2), 177-183.

(118) Mirali, M.; Ambrose, S. J.; Wood, S. A.; Vandenberg, A.; Purves, R. W. Development of a Fast Extraction Method and Optimization of Liquid Chromatography-Mass Spectrometry for the Analysis of Phenolic Compounds in 
Lentil Seed Coats. J. Chromatogr. B Anal. Technol. Biomed. Life Sci. 2014, 969, 149-161. https://doi.org/10.1016/j.jchromb.2014.08.007.

(119) Neugart, S.; Rohn, S.; Schreiner, M. Identification of Complex, Naturally Occurring Flavonoid Glycosides in Vicia Faba and Pisum Sativum Leaves by HPLC-DAD-ESI-MS and the Genotypic Effect on Their Flavonoid Profile. Food Res. Int. 2015, 76, 114-121. https://doi.org/10.1016/j.foodres.2015.02.021.

(120) Ombra, M. N.; D ’Acierno, A.; Nazzaro, F.; Riccardi, R.; Spigno, P.; Zaccardelli, M.; Pane, C.; Maione, M.; Fratianni, F. Phenolic Composition and Antioxidant and Antiproliferative Activities of the Extracts of Twelve Common Bean (Phaseolus Vulgaris L.) Endemic Ecotypes of Southern Italy before and after Cooking. Oxid. Med. Cell. Longev. 2016, 2016, 1-11. https://doi.org/10.1155/2016/1398298.

(121) Bastianelli, D.; Grosjean, F.; Peyronnet, C.; Duparque, M.; Régnier, J. M.; Bastianelli ', D.; Regnier, J. M. Feeding Value of Pea ( Pisum Sativum, L.) 1. Chemical Composition of Different Categories of Pea. Anim. Sci. 1998, 67 (3), 609-619. https://doi.org/10.1017/S1357729800033051.

(122) Caldas, G. V.; Blair, M. W. Inheritance of Seed Condensed Tannins and Their Relationship with Seed-Coat Color and Pattern Genes in Common Bean (Phaseolus Vulgaris L.). Theor. Appl. Genet. 2009, 119, 131-142. https://doi.org/10.1007/s00122-009-1023-4.

(123) Huang, Y.; Chen, L.; Feng, L.; Guo, F.; Li, Y. Characterization of Total Phenolic Constituents from the Stems of Spatholobus Suberectus Using LC-DAD-MSn and Their Inhibitory Effect on Human Neutrophil Elastase Activity. Molecules 2013, 18 (7), 7549-7556. https://doi.org/10.3390/molecules18077549.

(124) Zou, Y.; Chang, S. K. C.; Gu, Y.; Qian, S. Y. Antioxidant Activity and Phenolic Compositions of Lentil (Lens Culinaris Var. Morton) Extract and Its Fractions. $J$. 
806

807 


\section{TABLES AND FIGURES CAPTIONS}

809 Table 1. Potential health effects of legumes consumption.

810 Table 2. Number of phytochemicals (and percentage) of each group of legumes in 811 relation to their family.

812 Figure 1. Qualitative heatmap of the phytochemicals distributed in lentils, chickpeas, 813 beans, peas, soybeans and peanuts. Overview (red: presence; green: absence). For a 814 detailed version, please see Figure S1.

815 Figure 2. PCA score plot 2D (A), loading plot (B) and PCA score plot 3D (C).

816 Figure 3. Venn diagram analysis of qualitative data in beans, chickpeas, lentils and 817 soybeans.

818

819 
821 Table 1. Potential health effects of legumes consumption.

\begin{tabular}{|c|c|c|}
\hline Disease & $\begin{array}{c}\text { Legumes consumption } \\
\text { effect }\end{array}$ & Mechanism of action \\
\hline CVD $^{\text {a }}$ & $\begin{array}{l}\mathrm{RR}(95 \% \mathrm{CI})=0.92(0.85- \\
0.99)^{13} \\
\text { Positive effect on CVD risk }\end{array}$ & $\begin{array}{l}\text { Relation with specific nutrients and components found } \\
\text { in legumes: } \\
\uparrow \mathrm{K}^{+23} \uparrow \mathrm{Mg}^{+2} 24 \uparrow \text { fiber }^{25} \text { cholesterol-free } \\
\text { Relation with various cardiometabolic risk factors found } \\
\text { in non-soy legumes: } \\
\downarrow \text { LDL cholesterol }{ }^{14,15} \downarrow \text { total cholesterol }{ }^{15} \downarrow \text { blood pressure } \\
\uparrow \text { weight management }^{16,17} \downarrow \text { glycemic index } \\
18,19 \downarrow \text { metabolic } \\
\text { syndrome risk factors }^{22}\end{array}$ \\
\hline $\mathrm{CHD}^{\mathrm{b}}$ & $\begin{array}{l}\mathrm{RR}(95 \% \mathrm{CI})=0.90(0.83- \\
0.99)^{13} \\
\text { Positive effect on CHD risk }\end{array}$ & $\begin{array}{l}\text { Relation with specific nutrients and components found } \\
\text { in legumes: } \\
\uparrow \mathrm{K}^{+23} \\
\text { Relation with various cardiometabolic risk factors found } \\
\text { in non-soy legumes: } \\
\downarrow \text { glycemic index }{ }^{18,19}\end{array}$ \\
\hline $\begin{array}{l}\text { Prostate } \\
\text { cancer }\end{array}$ & $\begin{array}{l}\mathrm{RR}(95 \% \mathrm{CI})=0.85(0.75- \\
0.96]^{26} \\
\text { Positive effect on prostate } \\
\text { cancer risk }\end{array}$ & $\begin{array}{l}\text { Relation with specific nutrients and components found } \\
\text { in legumes: } \\
\uparrow \text { phytoestrogens }{ }^{27}\end{array}$ \\
\hline $\begin{array}{c}\text { Colorectal } \\
\text { cancer }\end{array}$ & $\begin{array}{l}\mathrm{RR}(95 \% \mathrm{CI})=0.91(0.84- \\
0.98)^{36} \\
\text { colorectal cancer: RR }(95 \% \\
\mathrm{CI})=1.00(0.95-1.06)^{37} \\
\text { colon cancer: RR }(95 \% \mathrm{CI})= \\
0.97(0.83-1.15)^{37} \\
\text { rectal cancer: RR }(95 \% \mathrm{CI})= \\
0.99(0.78-1.25)^{37} \\
\text { Controversial effects on } \\
\text { colorectal cancer risk }\end{array}$ & $\begin{array}{l}\text { Relation with specific nutrients and components found } \\
\text { in legumes: } \\
\uparrow \text { fiber }^{25}\end{array}$ \\
\hline Stroke & $\begin{array}{l}\mathrm{RR}(95 \% \mathrm{CI})=0.98(0.86- \\
1.11)^{13} \\
\text { No effects on stroke risk but } \\
\text { possible effects on markers of } \\
\text { stroke risk }\end{array}$ & $\begin{array}{l}\text { Relation with specific nutrients and components found } \\
\text { in legumes: } \\
\uparrow \mathrm{K}^{+23} \\
\text { Relation with various cardiometabolic risk factors } \\
\text { found in non-soy legumes: } \\
\downarrow \text { glycemic load } \\
\text { glyce }\end{array}$ \\
\hline Diabetes & $\begin{array}{l}\mathrm{RR}(95 \% \mathrm{CI})=0.93(0.83- \\
1.05)^{13} \\
\text { No effects on diabetes risk } \\
\text { but possible effects on } \\
\text { markers of diabetes }\end{array}$ & $\begin{array}{l}\text { Replacement animal protein for vegetable protein improves } \\
\text { glycemic control of diabetes }{ }^{19} \\
\text { Relation with various markers of glycemic control }\left(\mathrm{HbA}_{1} \mathrm{c}\right. \\
\left.{ }^{\mathrm{c}} \text { and fructosamine }\right)^{18} \\
\text { Relation with various diabetes risk factors found in } \\
\text { non-soy legumes: } \\
\downarrow \text { metabolic syndrome risk factors }{ }^{22}\end{array}$ \\
\hline $\begin{array}{l}\text { Satiety and } \\
\text { food intake }\end{array}$ & $\begin{array}{l}\operatorname{RoM}^{\mathrm{d}}(95 \% \mathrm{CI})=1.31 \\
(1.09-1.58)^{38} \\
\text { Positive effects on acute }\end{array}$ & $\begin{array}{l}\text { Relation with specific nutrients and components found } \\
\text { in legumes: } \\
\downarrow \text { glycemic index }{ }^{38} \downarrow \text { fat content }{ }^{38} \uparrow \text { fiber }^{38}\end{array}$ \\
\hline
\end{tabular}




\begin{tabular}{|l|l|l|}
\hline & satiety & $\begin{array}{l}\text { Relation with various risk factors found in non-soy } \\
\text { legumes: }\end{array}$
\end{tabular}

blood sugar and insulin levels stabilization ${ }^{12}$

822 a CVD: cardiovascular disease, ${ }^{\mathrm{b}} \mathrm{CHD}$ : coronary heart disease, ${ }^{\mathrm{c}} \mathrm{HbA}_{1} \mathrm{c}$ : glycated hemoglobin;

823 dRoM: ratio of means 
824 Table 2. Number of phytochemicals (and percentage) of each group of legumes in 825 relation to their family.

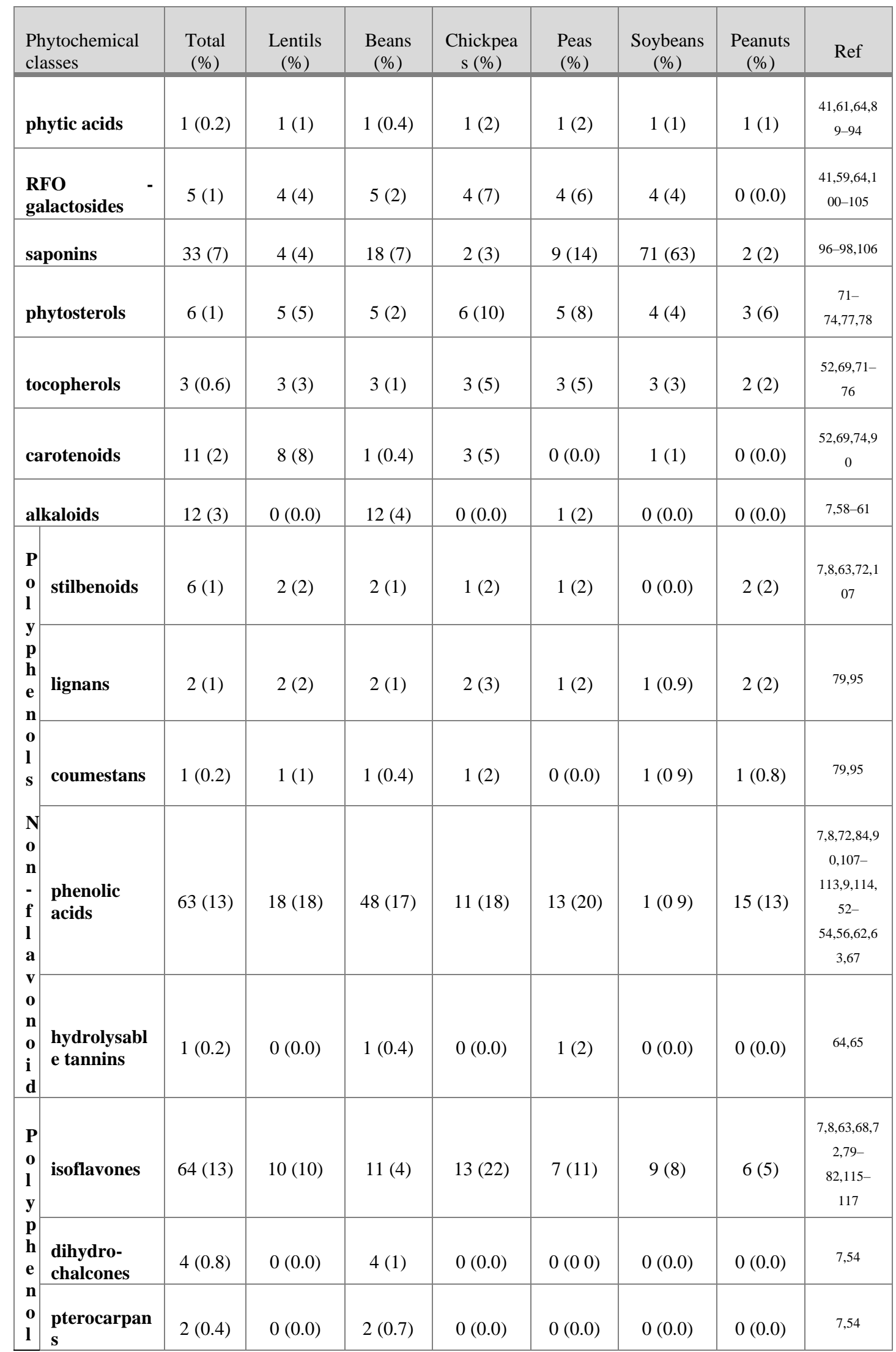




\begin{tabular}{|c|c|c|c|c|c|c|c|c|c|}
\hline $\begin{array}{l}\mathbf{F} \\
\mathbf{l} \\
\mathbf{a} \\
\mathbf{v}\end{array}$ & flavones & $31(6)$ & $9(9)$ & $19(7)$ & $3(5)$ & $6(9)$ & $0(0.0)$ & $6(5)$. & $\begin{array}{c}7,8,53,54,5 \\
6,62,63,72, \\
85,95,107, \\
111,113,11 \\
8\end{array}$ \\
\hline $\begin{array}{l}\text { n } \\
\text { o } \\
\text { i } \\
\text { d } \\
\text { s }\end{array}$ & flavonols & 79 (17) & $13(13)$ & $64(23)$ & $8(13)$ & $5(8)$ & $8(7)$ & $6(5)$ & $\begin{array}{c}7-9,52- \\
57,62,67- \\
69,72,84,8 \\
5,95,107,1 \\
10,111,113 \\
, 115,118- \\
120\end{array}$ \\
\hline & flavanones & $20(4)$ & $1(1)$ & $12(4)$ & $0(0.0)$ & $3(5)$ & $4(4)$ & $3(3)$ & $\begin{array}{c}7,8,53,54,6 \\
8,110,113, \\
118\end{array}$ \\
\hline & flavanonols & $4(0.8)$ & $0(0.0)$ & $3(1.1)$ & $0(0.0)$ & $0(0.0)$ & $0(0.0)$ & $2(2)$ & $\begin{array}{c}7,8,54,62,6 \\
3\end{array}$ \\
\hline & flavanols & $17(4)$ & 7 (7) & $16(6)$ & $1(2)$ & $5(8)$ & $1(0.9)$ & $3(3)$ & $\begin{array}{c}7- \\
9,52,54,63, \\
69,72,83- \\
88,110,113\end{array}$ \\
\hline & $\begin{array}{l}\text { condensed } \\
\text { tannins }\end{array}$ & 90 (19) & $10(10)$ & $23(8)$ & $0(0.0)$ & $0(0.0)$ & $1(0.9)$ & $65(54)$ & $\begin{array}{c}7- \\
9,52,61,64, \\
85,86,88,1 \\
07,112,121 \\
-124\end{array}$ \\
\hline & $\begin{array}{l}\text { anthocyanid } \\
\text { ins }\end{array}$ & $21(4)$ & $2(2)$ & $21(8)$ & $0(0.0)$ & $0(0.0)$ & $2(2)$ & $0(0.0)$ & $\begin{array}{c}52- \\
56,67,84,8 \\
5\end{array}$ \\
\hline & razilin & $1(0.2)$ & $0(0.0)$ & $1(0.4)$ & $0(0.0)$ & $0(0.0)$ & $0(0.0)$ & $0(0.0)$ & 7,8 \\
\hline & |ualene & $1(0.2)$ & $1(1)$ & $1(0.4)$ & $1(1.7)$ & $1(1.5)$ & $0(0.0)$ & $1(0.8)$ & 7,8 \\
\hline & OTAL & $\begin{array}{c}478 \\
(100)\end{array}$ & $101(100)$ & $\begin{array}{c}276 \\
(100)\end{array}$ & $60(100)$ & $\begin{array}{c}66 \\
(100)\end{array}$ & $112(100)$ & $\begin{array}{c}120 \\
(100)\end{array}$ & \\
\hline
\end{tabular}

827 
829 Figure 1. Qualitative heatmap of the phytochemicals distributed in lentils, chickpeas, 830 beans, peas, soybeans and peanuts. Overview (red: presence; green: absence). For a 831 detailed version, please see Figure S1.

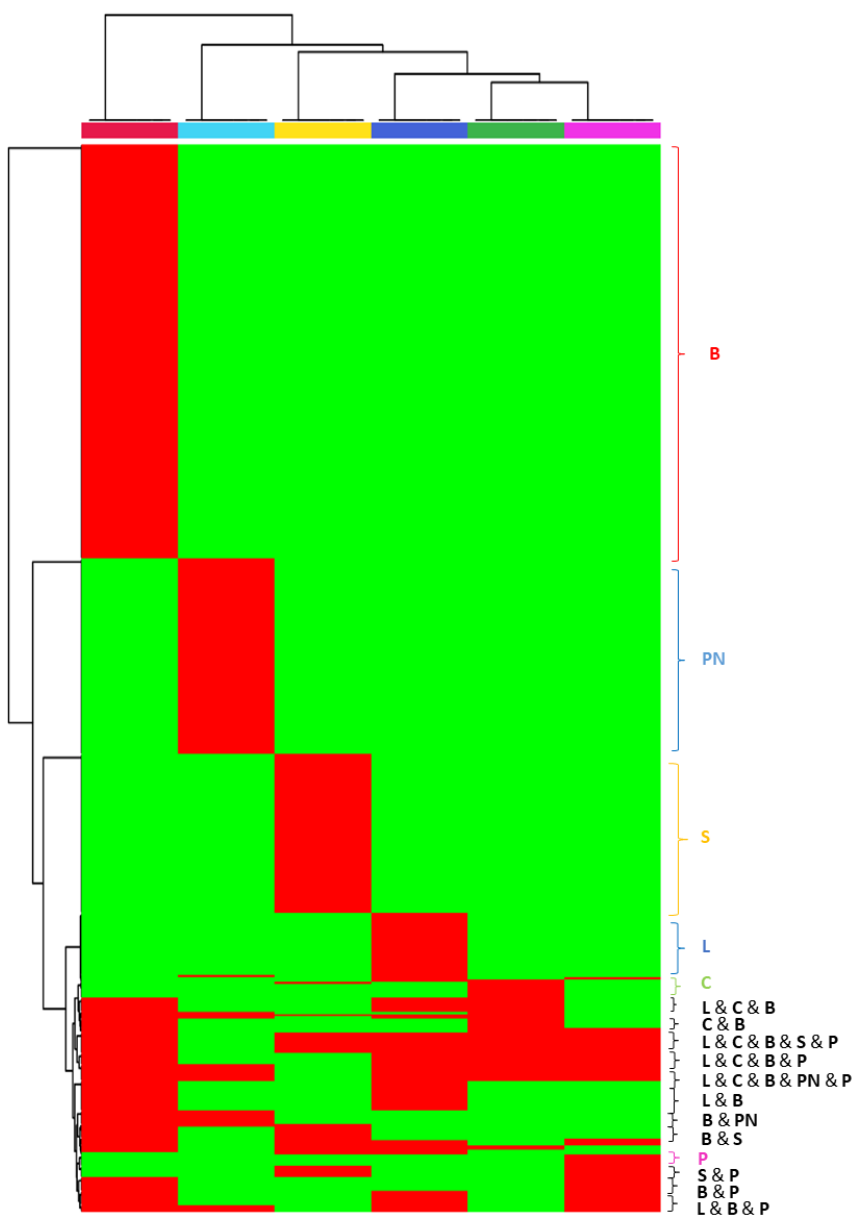

PC477; PC475; PC474; PC472; PC471; PC464; PC461; PC460; PC458; PC454; PC432; PC430; PC428; PC425; PC423; PC420; PC418; PC417; PC416; PC415; PC414; PC413; PC412; PC410; PC407; PC403; PC402; РC401; РC400; PC399; РC398; РC396; PC395; PC394; PC393; PC392; PC389; PC382; PC369; PC367; PC365; PC364; PC361; PC360; PC356; PC355; PC353; PC352; PC350; PC349; РC348; РC347; PC345; PC344; РC343; PC342; PC341; PC340; PC339; РC338; PC337; PC336; PC284; PC281; PC279; PC278; PC273; PC271; PC270; PC269; PC268; PC266; PC265; PC264; PC261; PC258; PC257; PC256; PC254; PC253; PC252; PC251; PC242; PC241; PC240; PC239; PC229; PC228; PC227; PC225; PC224; PC223; PC222; PC221; PC219; PC218; PC217; PC216; PC215; PC214; PC213; PC212; PC211; PC210; PC209; PC207; PC206; PC205; PC203; PC201; PC199; PC198; PC197; PC196; PC194; PC192; PC176; PC175; PC145; PC140; PC139; PC138; PC136; PC135; PC133; PC132; PC131; PC130; PC129; PC128; PC127; PC126; PC125; PC123; PC103; PC102; PC99; PC98; PC97; PC95; PC93; PC89; PC86; PC85; PC81; PC79; PC71; PC70; PC69; PC68; PC67; PC65; PC64; PC62; PC58; PC56; PC55; PC53; PC51; PC47; PC45; PC44; PC37; PC31; PC26; PC24; PC23; PC22; PC21; PC20; PC19; PC18; PC16; PC12; PC11; PC9; PC8; PC5; PC1; PC4

PC469; PC468; PC465; PC462; PC426; PC419; PC388; PC386; PC385; PC384; PC383; PC380; PC379; PC378; PC377; PC376; PC375; PC374; PC373; PC372; PC371; PC354; PC335; PC334; PC333; PC332; PC331; PC330; PC329; PC328; PC327; PC326; PC325; PC324; PC323; PC322; PC321; PC320, PC319, PC318, PC317, PC316, PC315, PC314, PC313, PC312, PC311; PC310;

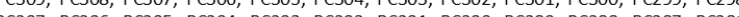
PC297; PC296; PC295; PC294; PC293; PC292; PC291; PC290; PC289; PC288; PC287; PC286; PC202; PC195; PC193; PC190; PC173; PC134; PC94; PC75; PC39; PC36; PC35; PC33; PC34

PC450; PC444; PC442; PC441; PC439; PC438; PC276; PC275; PC274; PC272; PC236; PC235; PC234; PC233; PC232; PC231; PC230; PC188; PC187; PC186; PC185; PC184; PC183; PC182; PC181; PC180; PC179; PC178; PC171; PC170; PC169; PC168; PC167; PC166; PC165; PC164; PC163; PC162; PC161; PC160; PC159; PC158; PC157; PC156; PC155; PC154; PC153; PC152; PC151; PC121; PC120; PC119; PC118; PC117; PC116; PC115; PC114; PC113; PC112; PC111; PC110; PC109; PC108; PC107; PC106; PC46; PC43; PC41; PC42

PC470; PC 466; PC424; PC411; PC 405; PC381; PC370; PC368; PC2 49; PC247; PC245; PC238; PC237; PC208; PC147; PC142; PC60; PC50; PC49; PC48; PC40; PC38; PC32; PC28; PC27; PC14; PC25 PC143; PC84; PC82; PC78; PC29; PC77 PC433; PC408; PC397; PC282; PC57; PC255

PC476; PC456; PC443; PC421; PC149; PC146; PC122; PC72; PC90 PC459; PC422; PC409; PC66; PC88

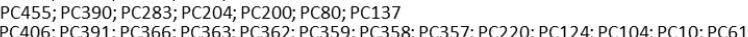
PC406; PC391; PC366; PC363; PC362; PC35;
PC463; PC262; PC259; PC250; PC3; PC141

PC451; PC437; PC436; PC100; PC226
PC427: PC260; PC244; PC59; PC148

PC453; PC452; PC448; PC434; PC447
PC277; PC246; PC191; PC63; PC30; PC54
PC346; PC285; PC280; PC267; PC7; PC17

Note. The phytochemical name of each PC-number code is shown in Table S2. Detailed information is also stated on Table S3 and Table S4. Legume groupings with less than four common compounds are not displayed in this figure. 
841 Figure 2. PCA score plot 2D (A), loading plot (B) and PCA score plot 3D (C).

A

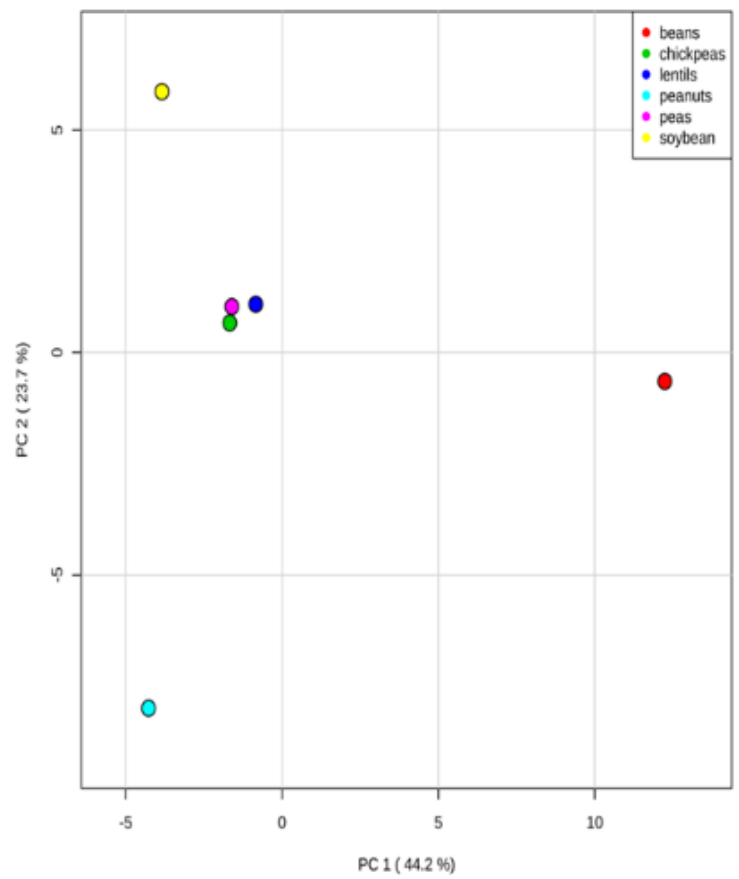

C

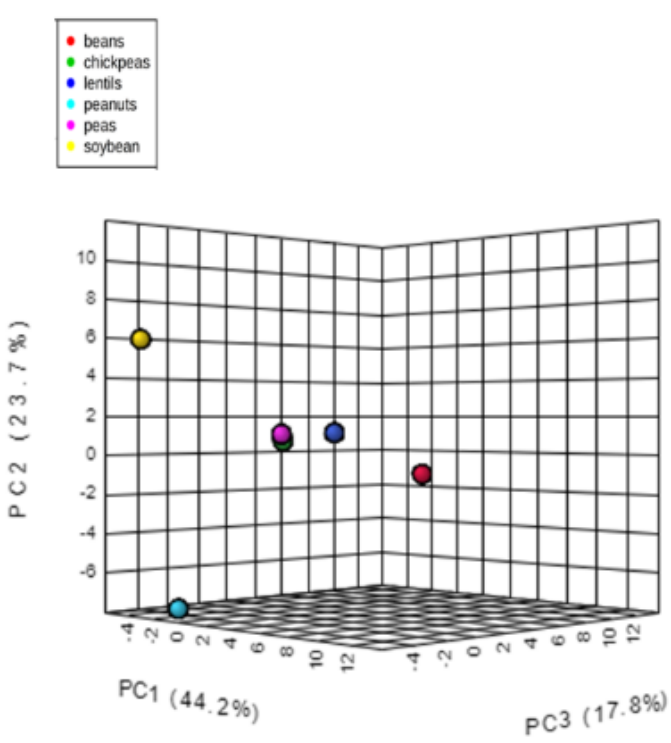

B

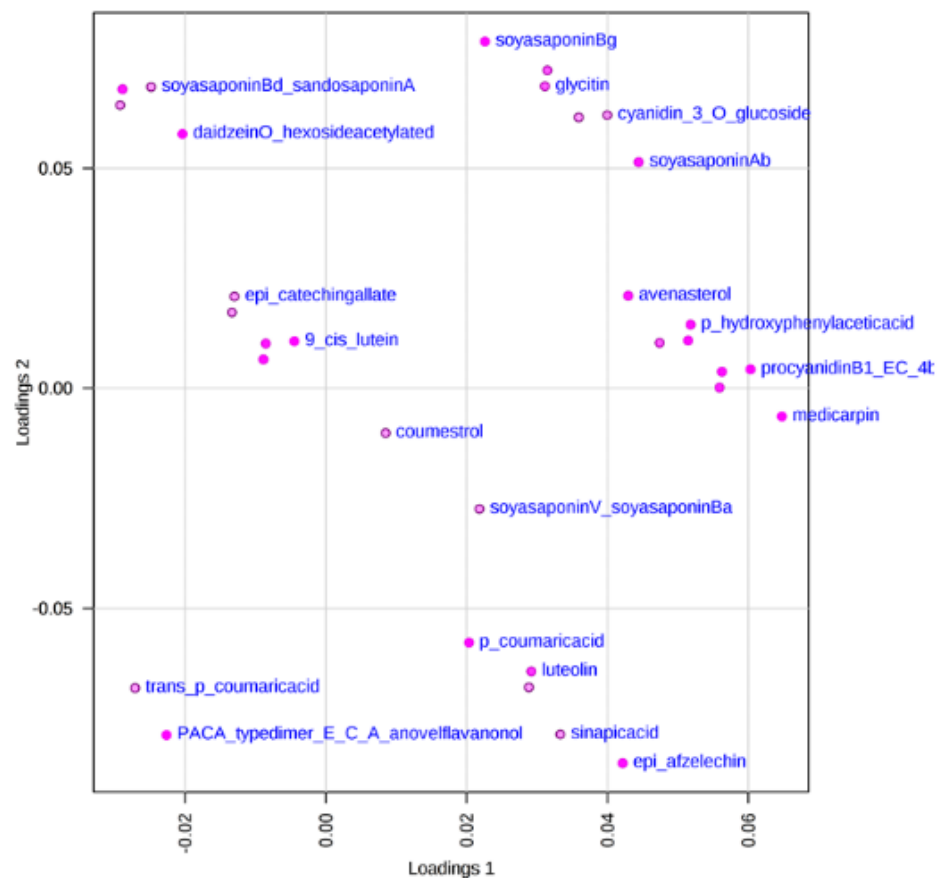


846 Figure 3. Venn diagram analysis of qualitative data in beans, chickpeas, lentils and 847 soybeans.

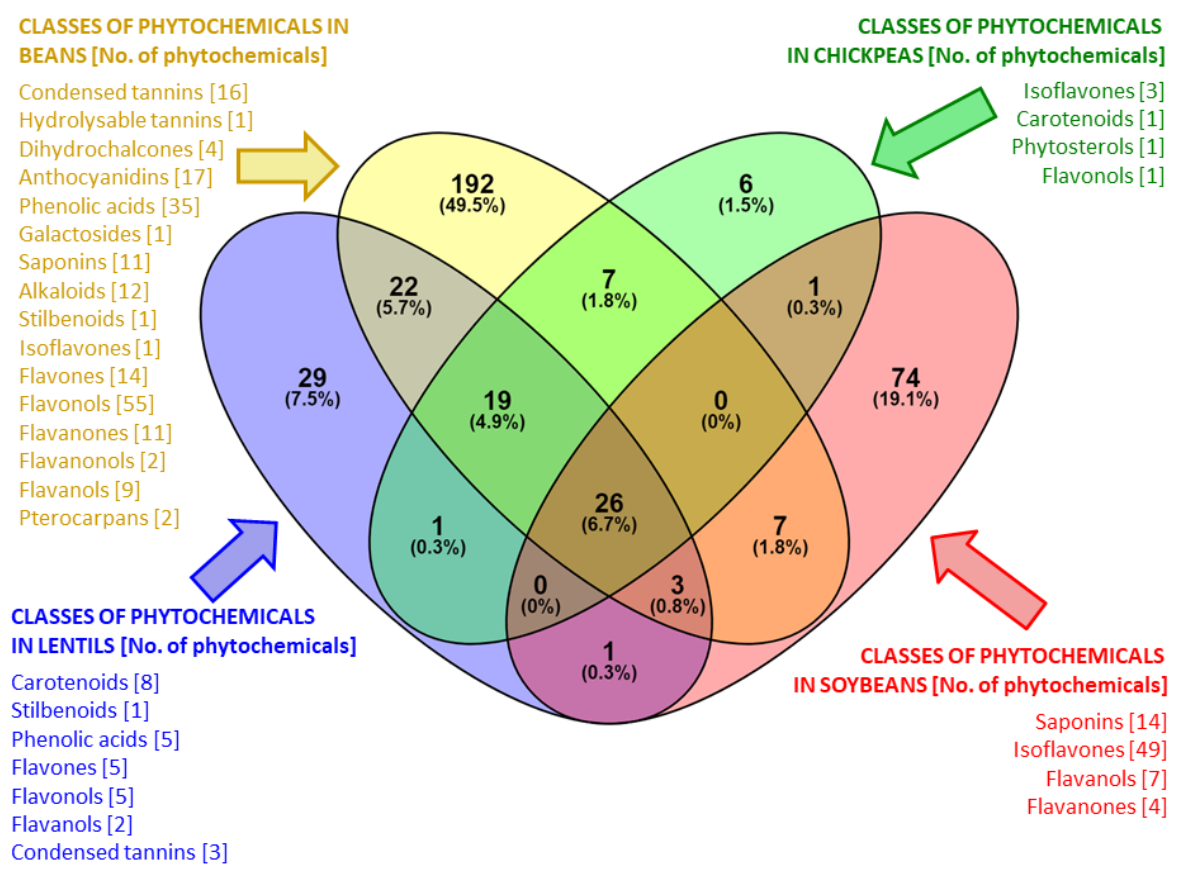

848 Note. Bold numbers mean the total amount of phytochemicals on beans, chickpeas, lentils and 849 soybeans and phytochemicals shared by each legume combination. In brackets, the percentage of 850 phytochemicals over total number of phytochemicals. 
852 FOR TABLE OF CONTENTS ONLY

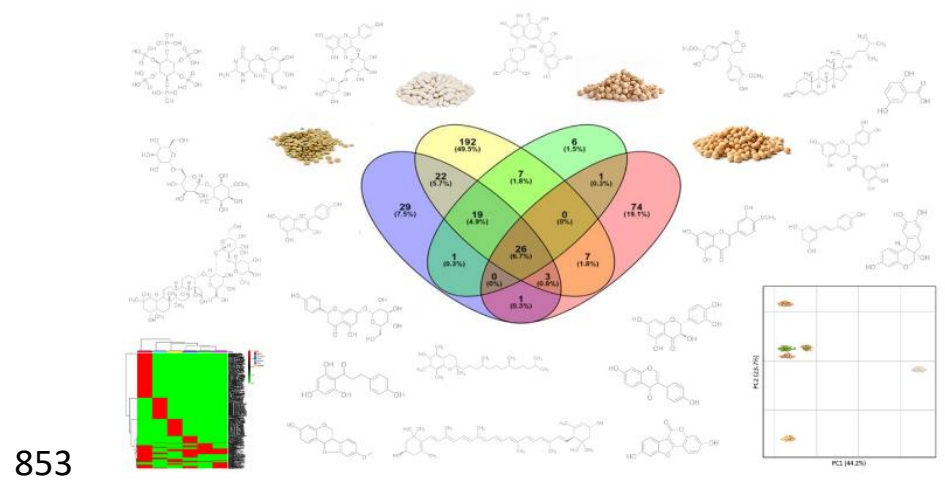

854

855 